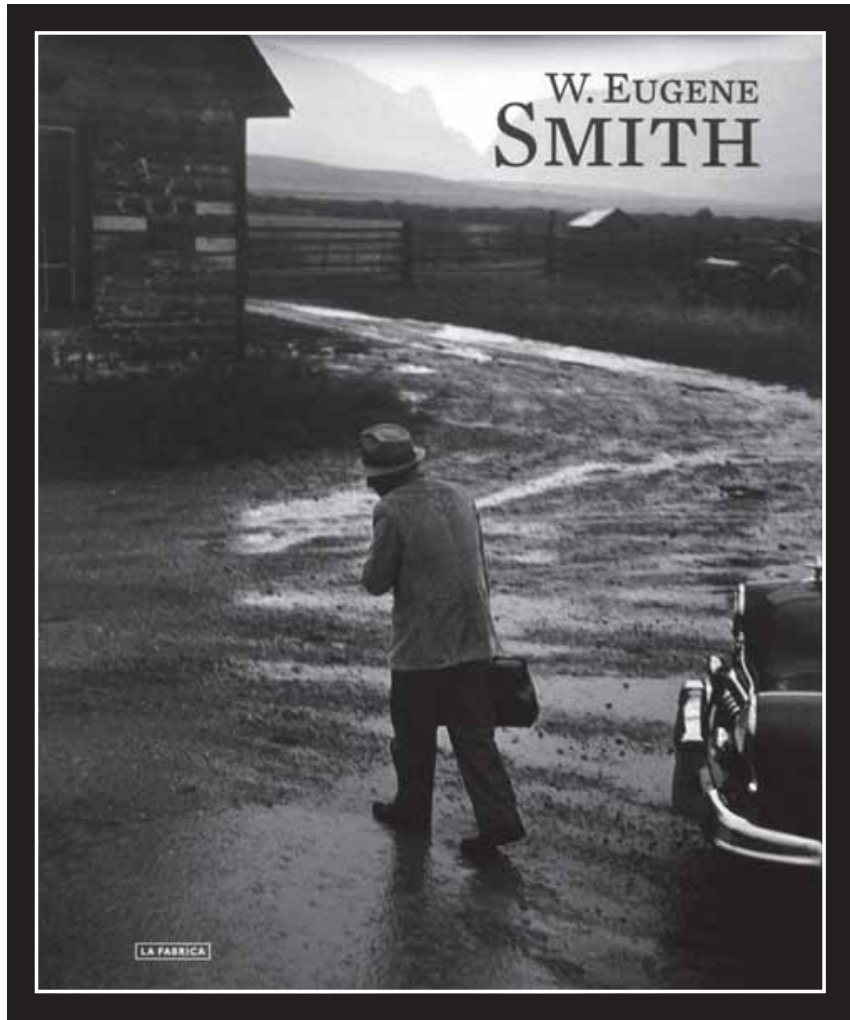

Más real que la realidad: W. Eugene Smith, coordenado por Doménico Chiappe. Madrid: La Fabrica Editorial, 2008. 238 p. 


\section{Más real que la realidad: vida e obra de W. Eugene Smith}

Daniel de Oliveira Figueiredo*

Publicado em 2008 pela editora espanhola La Fabrica, a obra Más real que la realidad (ainda sem versão em português) se apresenta como um dossiê da vida e obra do fotógrafo W. Eugene Smith. Permeando todo o livro, fotografias são complementadas com legendas e comentários do próprio fotografo, além de textos biográficos, análises de suas produções e avaliações holísticas de seu arquivo fotográfico.

A leitura se aproxima da sensação de descoberta plena da obra de um artista que, por meio de declarações pessoais e depoimentos biográficos, deflagram a maneira como as suas experiências de vida influenciaram suas reportagens fotográficas.

O primeiro capítulo reapresenta, como prólogo, o famoso ensaio El Pueblo Español. A reportagem fotográfica expõe imagens realizadas em sua viagem pela Espanha, aprofundando-se, verbal e imageticamente, na experiência do fotógrafo em Deleitosa, pequeno povoado (de aproximadamente três mil moradores) a sudoeste de Madri.

Anotações vinculadas a cada fotografia, feitas pelo próprio fotógrafo, contextualizam situações específicas em que esteve envolvido nos anos 50. Mais tarde, enviou as imagens e os textos à revista Life. Somos apresentados às peculiaridades da vida espanhola por um olhar analítico. Pequenos detalhes em Deleitosa são suficientes para uma reflexão humanizada sobre a vida cotidiana de pequenos vilarejos espanhóis que sofreram as consequências do regime fascista de Franco.

Costumes higiênicos diários, trabalhos campesinos e festas folclóricas foram retratados por Smith, que sofreu pressão pelo registro visual da

\footnotetext{
* Relações públicas. Mestrando do Programa de Pós-Graduação em Comunicação da Universidade Estadual de Londrina (UEL). Bolsista Capes.
} 
população. Diariamente era questionado pela polícia local sobre sua presença e a ele, inclusive, não foram permitidas anotações escritas de nomes e datas pontuais, apenas impressões.

O segundo capítulo remete à vida e à importância do arquivo fotográfico de Smith, pontuado por falas e depoimentos do próprio fotógrafo. Escrito por Britt Salvensen (diretora e curadora chefe do acervo fotográfico da Universidade do Arizona), é intitulado: W. Eugene Smith: el artista y el archivo.

O fotógrafo nasceu em 30 de dezembro de 1918, em Wichita, estado de Kansas (EUA), filho de família abastada. Possuía um cômodo de revelação em sua própria casa e herdou coleções de fotografias, paixão de sua mãe, Nettie Lee Caplinger Smith. Começou a fotografar com apenas quinze anos e cobria, casualmente, eventos esportivos para um jornal local. Sua primeira grande e comentada reportagem foi sobre a seca do estado de Kansas, publicada no The New York Times.

A crise financeira de 1929 derrubou as finanças da família e Smith presenciou seu pai em uma tentativa de suicídio. A cobertura sensacionalista da imprensa de Kansas sobre o fato desencadeou no fotógrafo certa impaciência com o jornalismo sensacionalista e o motivou a mudar tal situação. Sua primeira formação em fotografia se deu após sua mudança para Nova Iorque, com sua mãe e irmão. Na oportunidade, lançou-se no fotojornalismo com intensidade, iniciando seus trabalhos na revista Newsweek. Neste período, casou-se com Carmen Martinez e teve dois filhos.

O texto biográfico de Salvensen conta como, após sua chegada em Nova Iorque, Smith iniciou um processo de consolidação estético e político em suas fotografias, contrapondo-se às praticas editorais da época. Neste ímpeto, em julho de 1943 foi contratado pela editoria Ziff-Davis Publisinh como correspondente de guerra, destinado aos porta-aviões Independence e Bunker Hill. Insatisfeito com sua posição, retornou aos Estados Unidos e ingressou no corpo editorial da revista Life para fotografar a guerra de maneira mais próxima e real. Cobriu o desembarque de tropas militares em Saipan e Iwo Jima, 
além de realizar uma reportagem sobre o cotidiano de guerra do soldado americano Terry Moore, em Okinawa.

Segundo Salvensen (p.68), essas experiências marcaram o fotógrafo e "allí, Smith no sólo fue testigo de la brutalidad del combate en tierra, sino que además vio sus efectos en los civiles. [...] Cada vez que apretaba el disparador, le escribió a su mujer, era como lanzar un grito de condena con la esperanza de que perdurase a lo largo de los años".

Engajado politicamente, continuou com o fotojornalismo no pósguerra trocando de revistas e agências, com uma passagem de três anos pela Magnum. Neste período realizou seus ensaios e reportagens mais conhecidas e teve maior liberdade criativa, aspecto pelo qual batalhou durante toda sua carreira.

Em 1975, na Universidade do Arizona, foi criada a instituição de preservação e armazenamento fotográfico que até hoje conserva a obra de grandes fotógrafos, inclusive de Smith. Idealizada por Ansel Adams, o museu recebeu todo o seu vasto material, totalizando uma área de 280 metros quadrados com cerca de duas mil fotografias e filmes originais, que contam e refletem as paixões, êxitos e frustrações do fotógrafo.

Fotografias e experiências de vida, mescladas, demonstram que a "extraordinaria influencia que ejerció Smith en otros fotógrafos se debe no sólo a su habilidad como realizador de fotos, sino también a la fuerza de su personalidad”, testemunha Salvensen (p.72).

No terceiro capítulo, Enrica Viganò reflete características das imagens de Smith como agentes construtores da realidade e do campo teórico da fotografia. Preocupada com aspectos filosóficos da contribuição do fotógrafo, recorre às dimensões estética e técnica para compor o texto La obsesión creativa: entre la virtud y la maldición.

Traçando um comparativo entre os contextos de produção dos principais ensaios de Smith com sua personalidade, Viganò (p.73) defende que, para o fotógrafo, o núcleo da obsessão com que realizava suas imagens consistia em transformar em fotografias sua verdade, tendo sob controle todo o processo de comunicação inerente ao gesto fotográfico. 
"Documentar la realidad es sólo el punto de partida; reflejar en la fotografía las emociones que esa realidad transmite es la única forma posible, auténtica e necesaria de escribir con la luz”. Dessa forma, a integridade pessoal e a função social da fotografia são inseparáveis na necessidade de transmitir, pela imagem, um pensamento ou sentimento.

Percorrendo os ensaios de Smith com pormenores históricos, sociais e políticos, Viganò se convence de que os corpos editoriais das revistas, refletindo seus desejos e intenções particulares, não foram suficientes para esgotar o potencial comunicativo e criativo do fotógrafo, uma vez que definiam limites e prazos para os ensaios. Com isso, estimulavam Smith a transgredir e o deixavam insatisfeito, pois ele "queria cambiar el mundo com sus imágenes” (p.77).

Viganò (p.79) explica que, para Smith, "todo debe estar al servicio de este propósito, puesto que las imágenes no sólo han de mostrar, sino también demostrar. El fotógrafo tiene el derecho y el deber de participar y su injerencia ayuda en la lectura de la verdad".

Em um relato caro à parte técnica, relata que o fotógrafo dificilmente se surpreendia quando revelava seus rolos de filmes, pois todos os aspectos da linguagem estavam muito claros em seu pensamento. Ele demonstrava possuir um controle total de luz e composição, além de, em algumas ocasiões, mandar repetir as ações fotografadas para melhor construir sua imagem.

De maneira geral, afirma Enrica Viganò, quem melhor entendeu e explicou sua maneira de encarar a realidade concreta, subjetivando-a a partir de sua individualidade e a transformando em fotografia foi o próprio W. Eugene Smith. Viganò, na página 80, cita um trecho do discurso proferido pelo fotógrafo numa conferência na Universidade de Michigan:

No lo hago, a menos que lo crea absolutamente necesario para contar algo que no parece estar ocurriendo. Si, en el proceso de comprensión de mi sujeto, quiero y siento que esa fotografía serviría para contar una historia honesta, entonces puedo tomar la decisión de hacerlo. (SMITH apud VIGARÒ, 2008, p.80). 
Na terceira e última parte textual do livro, é apresentada uma declaração biográfica do fotógrafo escrita por ele próprio. Em tom mais intimista, se comparado aos textos anteriores, Smith (em primeira pessoa) passeia por toda sua vida, desde a inocência dos catorze anos, até uma reflexão aprofundada de sua arte e profissão.

Conta o autor-fotógrafo a contribuição do início de sua carreira, na produção de imagens desportivas e na cobertura da seca que assolou a região onde nasceu. Na primeira situação, adquiriu reflexos necessários para qualquer modalidade fotográfica, tendo oportunidade de treiná-los; na segunda, iniciou um processo de consolidação estética.

Refletindo suas atitudes de jovem, Smith relembra episódios na universidade que moldaram seu caráter, definiram seus rumos como profissional e embasaram ações que, mais tarde, demonstrariam coerência. Sua mudança para Nova Iorque (local onde se fixou profissionalmente) deu-se em razão de uma confusão com notas baixas, questionadas por ele junto a um de seus professores na universidade. Com espírito indagador, sentiu-se lesado e decidiu abandonar os estudos formais em história.

Deixando transparecer orgulho pelo sucesso de suas reportagens na revista Life, relata as contradições que o faziam se desentender com os editores e como se comportava para que os ensaios fossem os mais fiéis possíveis à realidade. Finaliza o depoimento de sua passagem pela revista construindo uma argumentação sobre o papel dos meios de comunicação e do jornalismo, em especial a televisão.

Indica a contribuição de várias pessoas na realização de suas reportagens de sucesso, em particular Wilson Hicks, editor de fotografia da revista Life de 1937 a 1950. É deste editor a frase que dá nome ao livro. Ele afirmou, certa vez, que as composições fotográficas de Smith eram mais reais que a própria realidade. Hicks também foi protagonista de grande desentendimento, quando pediu ao fotógrafo para deixar de lado seus ideais e doar-se de maneira plena ao fotojornalismo.

Também relata seu percurso técnico durante a profissão. Quando mais jovem, preparava a fotografia de antemão e utilizava muito o flash. 
Mais maduro, entendeu estes recursos como um erro e alegou certo arrependimento. Concluiu, depois de encerrar sua trajetória como fotojornalista, que não se pode deixar técnicas mecânicas sobrepujarem a intenção real do fotógrafo, devendo utilizá-las sem preocupação, mas com esmero de composição e verdadeiro cuidado com o objeto em cena.

Neste contexto de cuidado com o fotografado, Smith (p.86) alude que "en todo momento tengo en mente a las personas a quienes estoy fotografiando". E, dessa maneira, minava o constrangimento que o ato fotográfico pode acarretar e demonstrava cuidado paternal com a obtenção daimagem.

Argumenta, finalizando sua declaração autobiográfica, a valorização do outro em seu gesto de fotografar. Na página 88, o fotógrafo declara: "Siempre busco lo discordante en la situación. Me enfadan mucho determinadas situaciones, pero no las personas que se ven envueltas en ellas. En lo que me atañe, simplemente acepto, tranquilamente, que la fotografía es arte”.

Após o texto autobiográfico, começa a apresentação da obra fotográfica de Smith. São apresentados cinco de seus ensaios fotográficos, dispostos em ordem cronológica, exibindo-se apenas as fotografias, com raras legendas.

O primeiro, Médico Rural (1948), depõe a sacrificada rotina de um médico rural em vilarejos americanos; em seguida, o ensaio $L a$ Comadrona (1951) retrata a difícil vida de uma mulher negra na região sul dos Estados Unidos, que atua autonomamente como enfermeira; o terceiro ensaio fotográfico, Un Hombre Piadoso (1954), documenta o trabalho altruísta do Dr. Albert Schweitzer na África; já o quarto conjunto de fotografias, intitulado Pittsburgh (1955), apresenta seu primeiro trabalho como free-lance e que, ainda, está incompleto; enquanto o quinto e último ensaio, Minamata (1971-1973), denuncia os efeitos causados pela ação do mercúrio em uma região de pesca japonesa.

Finalmente, o curto texto de epílogo, Paseo hacia um jardín del paraíso, de autoria do próprio W. Eugene Smith, em 1954, contém 
reflexões do fotógrafo sobre sua experiência na guerra, sobre a condição humana frente a atrocidades gananciosas e o papel da fotografia no registro e aproximação da sociedade do terror dos conflitos.

Reflexão e deleite. O livro de Eugene Smith é um convite à reflexão sobre o engajamento, responsabilidade social e fotografia humanista, e suas imagens são um deleite para os amantes da fotografia. 